\title{
Erratum to: Nanofibrillated cellulose: properties reinvestigated
}

\author{
Ali Naderi • Tom Lindström
}

Published online: 13 October 2017

(C) Springer Science+Business Media B.V. 2017

Erratum to: Cellulose (2017) 24:1933-1945

DOI 10.1007/s10570-017-1258-1

In the original publication of the article, the co-author name Tom Lindström was mistakenly missed out.

The online version of the original article can be found under doi:10.1007/s10570-017-1258-1.

A. Naderi $(\varangle) \cdot$ T. Lindström Innventia AB, Box 5604, 11486 Stockholm, Sweden

e-mail: ali.naderi@innventia.com

T. Lindström

e-mail: tom.lindstrom@innventia.com

Also the affiliation of the corresponding author was provided incorrectly. It has been updated in this erratum. 